\title{
A STRUCTURAL DISCOURSE ANALYSIS OF THE ADVERTSISMENT OF “JOB \\ CAREER “ IN THE BATAM POS DAILY NEWSPAPER
}

\author{
Suswanto Ismadi Megah
}

\section{Dosen Tetap Prodi Pendidikan Bahasa Inggris UNRIKA Batam}

\begin{abstract}
In recent days the advertisement is a most effective way to sell or to market new products of the businessmen or producers. Due to the case, advertisement has great role in selling or marketing of the product. The producers use interesting advertisements to introduce their product by using interesting or different language style. This study focuses on the structural discourse of the advertisement used in Batam Pos daily newspaper in Batam island. Sample of the data obtained from job career column in January 2013. The advertisement consist of the opening, the body and the closing of the advertisement.
\end{abstract}

Keywords: Discourse Analysis, and Advertisement

\section{A. Introduction}

Language is an important tool that helps people to communicate among individuals or even nations. Wardhaugh $(1977 ; 3)$ explains that a language is a system of arbitrary vocal symbol can be used by human being for communication. Hence, a language has some characteristics. It is a system, arbitrary, vocal, symbol, human, and communication. In communication, language allows people to say thing to each other and express their communicative needs. It allows people to live, work and play together. To study about language in society is under the subject of a 
sociolinguistics. Thus, sociolinguistics is the study of a language in a society. According to Holmes (2006:1) sociolinguistics is the relationship between language and society. When people are interest in explaining why they speak differently in social life and social context, they should concern with identifying the social functions of language and the way it is used to convey social meaning. Moeliono (1992) states that function of language based on communicative can be used to declare something. Examining the information about the way language works, as well as about the social relationship in a community, and the way people signal aspects of their aspects of sociolinguitic study. According to Alwasliah (2002:6) language research is a part of the knowledge. Thus, to study of language is very important. Besides as the communication, language is also very often used to advertize the product.

Advertisement is always become something very crucial in modern era to offer. This advertisment is put anywhere in which we see the advertisement. According to Darmawan (2005:103) that Benyamin Franklin is the fisrt person who enriches information by adding illustration to give stronger effect. In Indonesia, advertisement can be found in written advertisement. And then the advertisement has strength at picture, language and location in where the advertisement put.

Every person who will advertize in order to make their product sold out. This is due to every producer wants their product sold out. To make the product sold out, so, the advertisement must be interesting either picture and fond. According to Seminto (2004) advertisement must be considered the acceptance of public. So, the key of success in advertisement is the acceptance of public. Therefore, In this study, the writer tries to analyze structure of the advertisement in the Batam Pos newspaper. 


\section{B. Structural Discourse of Advertisement}

Recently advertisement becomes more interesting in linguistic because viewed from the linguistic features in advertisement, particularly discourse analysis. So, discourse is a term becoming increasingly common in a wide range of academic and non-academic contexts. Sometimes it can seem as if each time it is used, it means something different. According to Kartomiharjo (1992:1) that discourse is a branch of linguistics which is developed to analyze a language unit more than a sentence.

In this case, there is a question, what is discourse, and what relation does it have to language? Within linguistics, discourse is often described as "language-in-use" or "socially situated text and talk", i.e., analysts ask how written, oral and visual texts are used in specific contexts to make meanings, as opposed to analysing language-as-an-abstract-system. Other disciplines (philosophy, history, sociology, anthropology, political science, media studies) tend to use the term to mean what is 'sayable' or 'thinkable' about a topic in any given political, social, historical, cultural context.

Furthermore, one way of conceptualising these two sets of approaches is to ask the question "Which is bigger - language or discourse?". In linguistics, language is bigger: discourses occur within (one of Chomsky's teachers) paved the way for linguists to analyse language above the sentence level, calling this unit of analysis 'discourse' (e.g., paragraphs, essays, interviews). Analysis therefore focuses on language in use, the relation of language to context and the relations of cohesion within a text. 
So, discourse analysis is a study to analyze language which is used scientifically either oral or written. In using language scientifically, it means the use of language daily in social interaction. So, the data of discourse analysis can be text either oral or written text. Sudaryat (2008: 154) states that substitution is a change from word to another word. This is common occurred in advertisement in order to be more interesting. In addition, Rani (2006: 87) states that is to differ the form of text can be differentiated that the sentence can be classified as text or not. So, it refers to the form of transcription in utterance. Adiel (2009) states that the structure of advertisement can be headline, body of the advertisement and the closing.

\section{Methodology}

This study can be classified as is descriptive qualitative research. According to Cresswel (2003: 178) qualitative research inquiry employs different knowledge claims, strategies of inquiry, and methods of data collection and analysis. Then Narbuko \& Achmadi (1997: 44) in Ningsih (2007) adds that qualitative data tend to be in the form of words than series number. Using the qualitative data the writer wants to describe the advertisement in the Batam Pos NewsPaper.

The sample which has been taken based on the population of this study is obtained from the Batam Pos Newspaper in January 2013. According to Babble (2001) that population and sample to describe in a research plan. Theses aspect such as a) to identify the population in the study, b) identify whether the sampling design for this population, c) identify the selection process for individual, d) identify whether the study will involve stratification of the population before selection the sample, and indicate the number of advertisement that would be taken, particularly advertisement of job career column. This advertisement is different from the advertisement which markets products. The analysis of this study focused on the structural 
elements of the advertisement. Thos consisted of the opening, the body, and the closing of the advertisement.

\section{Discussion}

Advertisement of the job career in the Batam Pos Newspaper aimed directly the objects, namely job seekers. This advertisement is different from the advertisement which will market product. The advertisement of job career has some features those will be discussed as follows:

\section{d.1 The opening of the Advertisement}

The first aim of the advertisement is to attract people to know the product. That is why the advertiser introduces or rememorizes the product already existed in market. Based the aim of the advertiser is to sell the product, so, it is required that the advertisement is interesting for perspective workers.

Data 1

\section{"Urgently Required"}

The opening of the advertisement in the data 1 is " urgently required". The letters printed in capital letters. This shows that the company really needs to recruit the candidate immediately. This explains how the company immediately need the worker to rush to apply it.

Data 2

"Vacancy" 
The opening of the advertisement in the data 2 is " vocancy". The letters printed in capital letters and bolded. This shows that the company provide a job for job seekers who wants to apply in that company. Therefore, this offers to the job seekers if they want job.

\section{d.2 The Body of the Advertisement}

The body of advertising has aim is to attract the desire of the objects (job seekers) to apply or join their companies. It is based on the objective of the advertiser who wants to attract the job seekers to apply at their companies, hence, the advertisement must be rational and objective. The reasons must be accepted by the job seekers.

Data 3

\section{"General Admin and Finance"}

Female, with accountingbackground

Active English. Chinese preferably

The body of the advertisement in the data 3 is "General Admin and Finance". The letters bold printed in it. This shows that the company needs of the job position as general admin and Finance. After that the advertisement also request some requirements such as Female, with accounting background, Active English. Chinese preferably. The last requirement is "Chinese preferably". This is clear very to show that Chinese applicant will be better.

Data 5

“Mechanic Mesin Kapal Crew Boat"

Pengalaman min.5 thn (water jet) 
The body of the advertisement in the data 4 is "Mechanic Mesin Kapal Crew Boat". The letters printed in bold. This shows that the company needs a mechanic who has got experience for 5 years. This company needs not fresh graduate but experienced worker. In addition, The body of the advertisement also shows specification of the job, namely experience in handling of water jet. So, the advertisement has give complete information in which the company require it.

\section{d.3 The closing of the Advertisement}

The closing of the advertisement consists of additional information which is related to the above. It is basically to give additional information which can be stated as reminding such as contact person or address in which the job seekers can contact if they are interested in the advertisement.

The next aim is expected to give the mindset of the objects (job seekers) that the job seekers can be interested to work in their companies. According to Adiel (2009:12) develop the closing of the advertisement there are two things to be considered selling approach and passive point. This can be seen in following data below.

Data 5

"Email your CV to"

Fb_batam@floramarine.com 
The closing of the advertisement in the data 5 is very simple is "Email your CV to". The letters printed is not in bold letters. This shows that the company just give facility to apply through email. This makes the applicant just send via email. This is cheaper and faster than sent via post office.

Data 6

"PT. RACER TECHNOLOGY BATAM"

Komp. Hijrah Karya Mandiri Blok F3

Batam centre

The closing of the advertisement in the data 6 is very more complete compared to the data 5 which is very simple just via email. While the data 6 shows the name of the company written in capital letters. This shows that the company existed and the applicant may come because the company also put its address after the name of the company.

\section{E. Conclusion}

It is based the structural discourse of the advertisement used in Batam Pos daily newspaper in Batam island. Sample of the data obtained from job career column in January 2013. data above. So, this study can be concluded that the advertisement consists for three parts, namely the opening, the body and the closing of advertisement. The opening obtained mostly used two types of opening, namely 'urgently required and vacancy". The body is the requirement needed by the company. This explains some requirements needed by the company. The closing consists of two types. The first is only email and the other is address of the company. 


\section{REFERENCES}

Alwasilah, Chaedar. 2005. Pengatar Penelitian Linguistik Terapan. Jakarta: Pusat Bahasa.

Abdul Rani, Bustanul Arifin, Martutik. 2006. Analisis Wacana Sebuah Kajian Bahasa dalam Pemakaian. Malang: Bayumedia Publishing.

Ferry Darmawan. 2005. "Posmodernisme Kode Visual dalam Iklan Komersial". Jurnal Komunikasi Mediator..

Halliday, M.A.K, and Ruqaiya Hasan, 1989. Language, Context, and Text: Aspect of Language in a Social-Semiotic Perspective. Victoria: Deakin University

Kartomiharjo,Soeseno. 1992. Analisis Wacana dan Penerapanya. Malang: IKIP Malang

Mulyana. 2005. Kajian Wacana Teori, Metode, dan Aplikasi Prinsip-Prinsip Analisis Wacana. Yogyakarta: Tiara Wacana

Siminto. 2004. "Analisis Wacana Iklan Televisi Royko Rasa Terasi” dalam Sumarlan, Agnes Adhani dan Indratmo. 2004. Analisis Wacana. Bandung: Pakar Raya

Yayat Sudaryat. 2008. Makna dalam Wacana. Bandung: Yrama Widya.

Wardhaugh, Ronald. 1977. Introduction to Linguistics. Toronto: Mc. Grow Hill Company.

Adiel87.blogspot.com/2009/Analisis Wacana_Iklan_Roncer.

En.wikipaedia/wiki/Discourse_Analysis 